\title{
Phytoplankton community structure of Lake Paoay and Lake Mohicap with notes on the first record of Ceratium (Dinophyta) in Lake Paoay
}

\author{
Kelsey Anne P. Sambitan ${ }^{2,3,4}$, Rey Donne S. Papa ${ }^{1,2,3}$, E Susana F. Baldia ${ }^{1,2,3 *}$ \\ ${ }^{1}$ Department of Biological Sciences, College of Science, ${ }^{2}$ Research Center for the Natural and \\ Applied Sciences, $\mathcal{E}^{3}$ Graduate School, University of Santo Tomas, 1015 Manila, Philippines; \\ ${ }^{4}$ Biological Sciences Department, College of Science and Computer Studies \\ De La Salle University-Dasmariñas, Manila, Philippines
}

\begin{abstract}
Phytoplankton are known to be biological indicators of changes in freshwater ecosystems. Hence, a study on the phytoplankton community structure revolving in their abundance and species composition which were then correlated with the abiotic factors was conducted in Lake Paoay and Lake Mohicap - two Philippine lakes that are of contrasting limnological characteristics and geological origins. An updated phytoplankton taxonomy of the two lakes resulted to a total of 42 genera of phytoplankton for Lake Paoay and 49 genera for Lake Mohicap wherein 17 genera are new records. Twelve genera were new records for Lake Paoay including the dinoflagellate Ceratium which were in bloom during the cold dry season January 2014 and had the highest density of $4.78 \times 10^{5}$ cells $\mathrm{mL}^{-1}$. This occurrence was then followed by a cyanobacterial bloom of Anabaena during the month of February with a density of $1.46 \times 10^{6}$ cells $\mathrm{mL}^{-1}$. Unusual blooms of Dinophyta and Cyanophyta might be attributed to the increase in the nutrient content which indicates that Lake Paoay is already undergoing eutrophication. On the other hand, the blue green algae Chroococcus dominated Lake Mohicap with the highest density in December and occurrences of dinoflagellates Glenodinium and Peridinium were noted. Based on the results of the study, it is evident that Lake Paoay and Lake Mohicap, in spite of obvious differences in location, lake origin and physical characteristics are undergoing similar conditions that result to phytoplankton blooms indicating increased nutrient levels that may be attributed to human-mediated increases in nutrient inputs, such as aquaculture and increased inputs of domestic wastes.
\end{abstract}

Keywords: phytoplankton community, Lake Paoay, Lake Mohicap, Ceratium, eutrophication, dinoflagellates

*To whom correspondence should be addressed sfbaldia@yahoo.com

\section{INTRODUCTION}

Phytoplankton play a key role in supporting the food chain of the entire aquatic ecosystem, contributing to primary productivity and serves as a link to biogeochemical changes. The 
variations in the phytoplankton community are regarded as biological indicators when monitoring and investigating water quality problems. The sensitivity of phytoplankton to temperature and nutrient concentrations are often manifested in species composition [1].

One of the major problems in any aquatic environment is eutrophication caused by anthropogenic activities. It is characterized by unsuspected excessive primary biomass production, low oxygen, decrease of submerged macrophyte, and increased frequency of anoxic events [2]. One factor affecting the rate of eutrophication is the amount of nutrients reaching the water or nutrient limitation. It can affect the abundance and species composition of phytoplankton. Changes in the concentration of nutrients, especially phosphorus, influence phytoplankton growth conditions which eventually determine species growth and composition. As pointed out by Reynolds et al. [3] and Padisák et al. [4], phytoplankton species with the same survival strategy form associations that potentially, and alternately, may dominate or co-dominate in a given environment.

In the case of most lakes, high primary production may, in time, eventually cause algal blooms, such as the case of Laguna de Bay, the largest lake in the Philippines, in which the cyanobacterium Microcystis aeruginosa, occurred during summer when irradiance is high [5]. Occurrence of dinoflagellates (Phylum Dinophyta) in freshwater environments can also be an indicator of declining water quality.

The objective of the study is to compare the abundance and composition of phytoplankton community structure in Lake Paoay and Lake Mohicap with regards to their contrasting limnological characteristics and make inferences as to the influence of its differing geological origins.

\section{Materials AND METHOdS}

Study site. Lake Mohicap is located in Brgy. Sta. Catalina, San Pablo City. It is the smallest of the seven Crater Lakes found in San Pablo City. It has an area of 22.89 h (228,900 sq.m.) and a maximum depth of $30 \mathrm{~m}$. According to the actual inventory of aqua structures conducted in 2004, there were 80 fish pen/fish cage operators in the lake occupying an area of 36,000 sq.m. It is a major source of Tilapia for Metro Manila and its neighbouring towns [6]. Lake Mohicap was divided into four sampling sites (Fig. 1); for each site, a transect line was made from the shoreline passing three sampling points as replicates.

Lake Paoay is found in the town of Paoay in Ilocos Norte, where it is the only natural lake found in the entire province [7]. Lake Paoay is also home to populations of Clarias batrachus (catfish), Oreochromis sp. (tilapia) and Neochanna sp. (mudfish) [8]. The lake has been experiencing a decline in its water level and quality especially during the dry period where evaporation is high combined with the extraction of water from irrigation [8]. This is due to the aquaculture practice in some parts of the lake which serves as an additional income to the local townsfolk residing in this

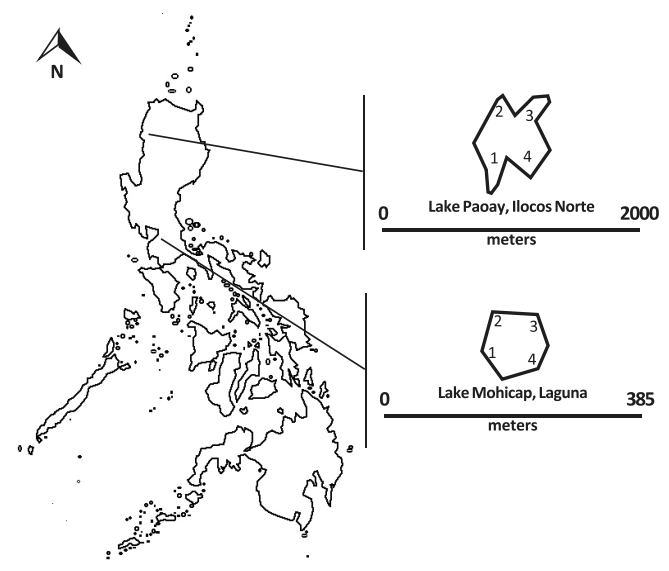

Figure 1. Maps of Lake Paoay and Lake Mohicap in the Philippines 
area. Lake Paoay was also divided into four sampling sites. The sampling sites were based on the previous researches done by the Bureau of Fisheries and Aquatic Resources in 1974 followed by Papa et al. [8].

Collection of water samples. Sampling was conducted from October 2013 to September 2014. Phytoplankton were collected from the assigned sites between $1000 \mathrm{~h}$ and $1300 \mathrm{~h}$ using a 3 L Plexi-glass water sampler that was deployed in three different depth layers -0 , 15, and $30 \mathrm{~m}$ (Lake Mohicap) and 0, 3 and $6 \mathrm{~m}$ (Lake Paoay). Samples collected from the different depth layers were fixed with Lugol's solution and stored in a 1-L tightly sealed bottles.

Phytoplankton analysis. For qualitative and quantitative analysis, aliquots of $1 \mathrm{~mL}$ were taken from $10 \mathrm{~mL}$ sample after centrifugation, and were done in replicate samples. These were then identified and counted using a haemocytometer counting chamber [9] with the aid of a compound microscope. Data on phytoplankton density were presented in terms of cells $/ \mathrm{mL}$.).

Nutrient analysis and Chlorophyll a determination. Water samples collected in the same site with the phytoplankton water samples were transported in an ice cooler and immediately stored at $0^{\circ} \mathrm{C}$ and were tested $e x$ situ. NitraVer 5 nitrate reagent powder pillows for nitrate $(\mathrm{mg} / \mathrm{L})$ and PhospoVer amino acid reagent powder pillows for phosphate $(\mathrm{mg} / \mathrm{L})$, respectively, were analyzed through the Hach DR/2010 portable data logging spectrophotometer. Measurement of Chlorophyll $a(\mathrm{mg} / \mathrm{L})$ was analysed using the methods of Strickland and Parsons [10].

Measurement of physico-chemical parameters. $\mathrm{pH}$, and conductivity $(\mu \mathrm{S} / \mathrm{m})$ were measured in situ using the Xplorer GLX (PASCO) water quality sensor. The probes were submerged into the water, at least $5 \mathrm{~cm}$ from the surface. Water transparency (m) was measured using a Secchi disc.

Statistical analysis. Multivariate statistical methods, such as non-metric multidimensional scaling and cluster analysis, are standard analytical tools which provide mechanisms to summarize large amounts of community and environmental data [11].

\section{RESULTS AND DISCUSSION}

Phytoplankton densities and species composition. A total of 42 genera were identified for Lake Paoay, with a total of 12 new records of genera from the four phyla observed (Table 1).

Four major algal phyla were found in Lake Paoay: Cyanophyta, Chlorophyta, Bacillariophyta, and Dinophyta. Chlorophyta had the greatest number of genera of (16) followed by Bacillariophyta (15) and Cyanophyta (11) (Table 1).

New genera of phytoplankton were observed from October 2013 to September 2014 in Lake Paoay. A total of seven new genera for Bacillariophyta, four Chlorophyta, two Cyanophyta and one Dinophyta were absent in the studies done by Villaroman et al. [12] and Stevenson et al. [13] in Lake Paoay.

No species from Euglenophyta were observed during the sampling period as opposed to the previous studies (water and sediments) conducted in Lake Paoay. This was because Euglenophyta prefer organic sources as nutrients rather than nitrate-nitrogen [12]. In addition, five genera of Bacillariophyta were again observed from the study of Stevenson et al. [13] although this was only observed from the sediments.

On the other hand, a total of 49 genera were identified in Lake Mohicap by which 17 are new 
Table 1. Updated listing of different phytoplankton genera in Lake Paoay

\begin{tabular}{|c|c|c|c|}
\hline Bacillariophyta & Cholorophyta & Cynanophyta & Dinophyta \\
\hline $\begin{array}{c}\text { Achnanthes**** } \\
\text { Coconeis**** } \\
\text { Coscinodiscus**** } \\
\text { Cyclotella* } \\
\text { Cymbella* } \\
\text { Fragilaria** }^{* *} \\
\text { Gomphonema*** } \\
\text { Gyrosigma**** } \\
\text { Melosira** } \\
\text { Navicula* } \\
\text { Nitzschia* } \\
\text { Pinnularia**** } \\
\text { Raphalodia**** } \\
\text { Surirella**** } \\
\text { Synedra** }\end{array}$ & \begin{tabular}{|c|} 
Ankistrodesmus** \\
Botryococcus** \\
Chlamydomonas**** \\
Chlorella** \\
Closterium** \\
Coelastrum**** \\
Cosmarium** \\
Eudorina**** \\
Golenkinia* \\
Kirchneriella** \\
Oedegonium**** \\
Oocystis** \\
Pediastrum** \\
Scenedesmus** \\
Staurastrum** \\
Tetraedron**
\end{tabular} & \begin{tabular}{|c|} 
Anabaena** \\
Chroococcus** \\
Gloeocapsa** \\
Lyngbya**** $^{* *}$ \\
Merismopedia** \\
Microcystis** \\
Marsonniella** \\
Oscillatoria** \\
Synechococcus**** \\
Synechocystis**
\end{tabular} & Ceratium**** \\
\hline
\end{tabular}

Table 2. Updated listing of different phytoplankton genera in Lake Mohicap

\begin{tabular}{|c|c|c|c|c|}
\hline Bacillariophyta & Chlorophyta & Cyanophyta & Dinophyta & Euglenophyta \\
\hline $\begin{array}{c}\text { Achnanthes**** } \\
\text { Amphora***** } \\
\text { Aulacoseira* } \\
\text { Coscinodiscus**** } \\
\text { Cyclotella** } \\
\text { Cymbella*** } \\
\text { Fragilaria*** } \\
\text { Gomphonema*** } \\
\text { Gyrosigma**** } \\
\text { Hantzschia**** } \\
\text { Melosira*** } \\
\text { Navicula** } \\
\text { Nitzschia* } \\
\text { Pinnularia**** } \\
\text { Placoneis**** } \\
\text { Rhopalodia**** } \\
\text { Stauroneis**** } \\
\text { Surirella*** } \\
\text { Synedra* }\end{array}$ & $\begin{array}{c}\text { Ankistrodesmus* } \\
\text { Asterococcus**** } \\
\text { Botrycoccus*** } \\
\text { Chlamydomonas**** } \\
\text { Chlorella* } \\
\text { Chlorococcom**** } \\
\text { Coelastrum*** } \\
\text { Crucigenia**** } \\
\text { Golenkenia**** } \\
\text { Kirchneriella** } \\
\text { Oocystis*** } \\
\text { Pediastrum* } \\
\text { Scenedesmus*** } \\
\text { Schroederia*** } \\
\text { Staurastrum* } \\
\text { Tetraedron*** }\end{array}$ & $\begin{array}{c}\text { Anabaena* } \\
\text { Chroococcus*** } \\
\text { Gleocapsa*** } \\
\text { Gomphosphaeria*** } \\
\text { Hapalosiphon**** } \\
\text { Merismopedia* } \\
\text { Microcystis*** } \\
\text { Nostoc*** } \\
\text { Oscillatoria* } \\
\text { Synechococcus*** }\end{array}$ & $\begin{array}{c}\text { Glenodinium }^{* * * * *} \\
\text { Peridinium }^{* * * *}\end{array}$ & $\begin{array}{l}\text { Cryptomonas } * * * * \\
\text { Trachelomonas } * * *\end{array}$ \\
\hline
\end{tabular}

records coming from five major algal phyla: Bacillariophyta, Chlorophyta, Cyanophyta, Dinophyta, and Euglenophyta (Table 2). These phyla were also observed by the Laguna Lake Development Authority from their report in the year 2005 with the exception of Euglenophyta.
Bacillariophyta had the greatest number of genera (19) followed by Chlorophyta (16), Cyanophyta (10) and both Dinophyta and Euglenophyta had two genera (Table 2). A total of nine genera for Bacillariophyta, five for Chlorophyta, one for Cyanophya, two for 
Dinophyta, and one Euglenophyta were absent in the studies of Cordero and Baldia, [14] and Zafaralla [15].

Different phytoplankton phyla dominated the two lakes. In Lake Paoay, Chlorophyta dominated while in Lake Mohicap, it was Bacillariophyta, specifically Nitzschia that dominated the lake suggesting that Lake Mohicap is now undergoing eutrophication. Species like Nitzschia palea, are found to be tolerant of organic pollution to sewage effluent effect at Lake Inlet [16]. In addition, Acnanthes was found in both lakes and for the first time, a bloom of Ceratium sp. (Dinophyta) was observed in Lake Paoay.

The highest density of Bacillariophyta in Lake Mohicap was observed during the wet month of October and declined towards August of the following year. A different scenario was observed in Lake Paoay, the low densities were observed from the months of October until December and started increasing towards the summer. The presence of Bacillariophyta is inversely proportional to the amount of dissolved oxygen in both lakes. When there is an increase in Bacillariophyta, there is a decrease in dissolved oxygen and vice versa.

The highest phytoplankton density for Lake Paoay $\left(1.46 \times 10^{6}\right.$ cells $\mathrm{mL}^{-1)}$ and Lake Mohicap $\left(3.51 \times 10^{6}\right.$ cells $\left.\mathrm{mL}^{-1}\right)$ was from the members of the Cyanophyta group. The highest density of Cyanophyta in Lake Paoay peaked during the month of February having a density of $1.46 \times 10^{6}$ cells $\mathrm{mL}^{-1}$, while the highest density of Cyanophyta in Lake Mohicap was during the months of October and December. The increase and decrease in the density can be related to the water quality parameters. Also, the densities of Cyanophyta based on the data, would indicate that nitrates is inversely proportional with the densities of this group. When there is an increase in the amount of nitrates, there is a decrease in the species of
Cyanophyta and the other way around. This may be due to the specific genera of Cyanobacteria in the area that does not metabolize nitrogen such as Chroococcus and Merismopedia.

A separate bloom of both Ceratium $\left(4.78 \times 10^{6}\right.$ cells $\left.\mathrm{mL}^{-1}\right)$ and the cyanobacterium Anabaena $\left(1.46 \times 10^{6}\right.$ cells $\left.\mathrm{mL}^{-1}\right)$ was observed in the months of January and February, respectively. According to Mowe et al. [17] less than $7 \%$ of total blooms that occurred in the tropical Asia were dominated by Anabaena.

The organisms' tendency to cluster indicate that they "choose" places offering the best conditions to live. For instance in Lake Mohicap, cyanobacteria dominated the months of October and December with a density of $3.5 \times 10^{6}$ cells $\mathrm{mL}^{-1}$. In addition, some freshwater dinoflagellates appeared in Lake Mohicap but in low abundance such as Peridinium and Glenodinium but were only observed during the wet to cold dry season and were no longer seen during the summer season.

Seasonal cycles of temperature, solar irradiance and precipitation as well as other disturbances will lead to changes in agricultural runoff, mixing in lakes, nutrient supply and plankton growth. According to Villaroman et al. [12] Manifestation of complex organisms such as Cyanophyta and Dinophyta occurs after the presence of Bacillariophyta which happened in Lake Paoay. The existence of certain phytoplankton genera like Cosmarium and Ceratium can be attributed to the characteristic feature of marine environment which took place during the formation of Lake Paoay, not to mention, that there are also other genera which are evident in the marine ecosystem. However, those genera found in Lake Mohicap are naturally occurring in a freshwater environment with the exception of some genera from Bacillariophyta. 
First record of occurrence of Ceratium sp. (Dinophyta) in Lake Paoay. The presence of Ceratium in Lake Paoay was observed during the cool dry months of December 2013 until February 2014 and was no longer seen during the wet season. In the Atlantic and Pacific oceans, some species of Ceratium are primarily found in colder water although it is sometimes found in the tropics [18].

Ceratium consists of a large number of species, many of which are very common and widespread; they constitute a characteristic and often dominant part of the plankton [18]. The genus Ceratium Schrank 1793 is the oldest genus name of dinoflagellates in use. This genus contained numerous (77) marine species and a few (7) freshwater species [19]. Morphological and molecular data supported the split of the marine and freshwater species at the genus level [19].

On the basis of their distribution, Graham [20] classified Ceratium species as either tropical, subpolar or cosmopolitan. Most Ceratium are tropical in distribution [21]. Also, Ceratium are normally found in water which is rich in nutrients like phosphates and nitrates, and is

\section{Shared Phytoplankton}

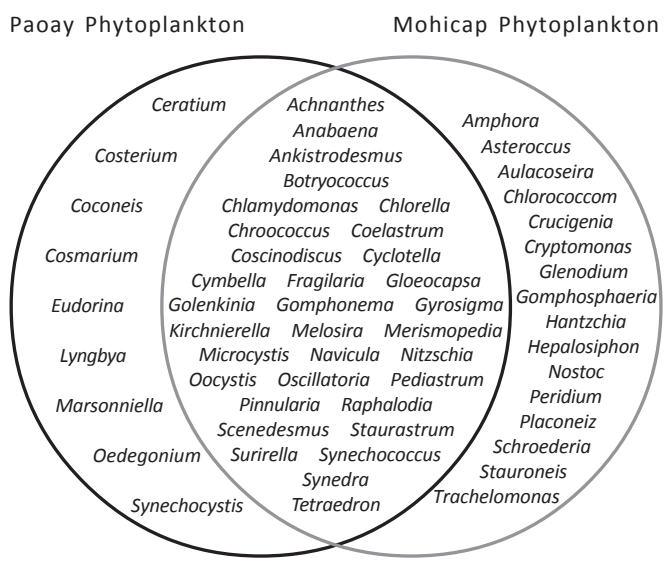

Figure 2. Venn diagram of phytoplankton genera of Lake Paoay and Lake Mohicap usually found in close association with Cyanophyta [22]. Tunisi et al. [23] suggested that this occurrence is related to the intense process of mixing which might have caused a sharp increase in the phosphorus content in the water column, hence, favoring the rapid bloom of this algae and exchange with cyanobacteria. Its unusual bloom had been recorded and considered an invasive species in several standing freshwater bodies of the world, such as in Hartbeespoort Dam in South Africa [24], and in a large enclosure located in Lake Biwa, Japan [25]. Although they thrive in nutrient rich environment, the studies of Graham and Bronikovsky [18] indicated that phosphorus concentration has no direct effect on the horizontal distribution of Ceratium. They did find that the relative phosphorus values in a given region bear some relation to the Ceratium flora but suggested that some factor associated with an increase in phosphorus was significant rather than the phosphorus itself. Besides from nutrient availability, Ceratium can also be observed in a great range of environmental condition such as temperature $\left(6.1-28.2^{\circ} \mathrm{C}\right)$, and $\mathrm{pH}(7.80-8.37)$. These environmental conditions were observed in Lake Paoay during its occurrence.

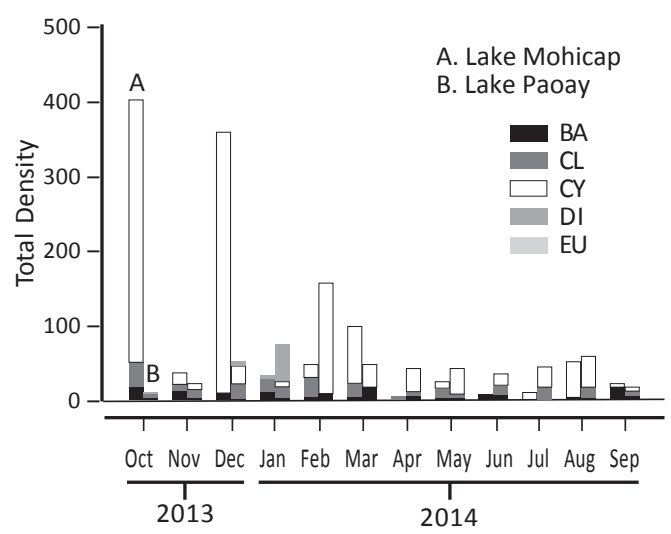

Figure 3. Total density of the different phytoplankton phyla in Lake Paoay and Lake Mohicap (Legend: BA - Bacillariophyta; CL - Chlorophyta; CY Cyanophyta; DI - Dinophyta; EU - Euglenophyta) 
Variations in physico-chemical parameters and its effect to the different phytoplankton communities in Lake Paoay and Lake Mohicap. Fluctuations in the different environmental parameters affect the phytoplankton community structure significantly (Fig. 4). The pattern of phytoplankton community and water quality are interdependent [26].

There was no variation in $\mathrm{pH}$ for both lakes with the highest $\mathrm{pH}$ notable in October and August in Lake Paoay (8.28) and Lake Mohicap (13.370), respectively. Such pH levels were still within the common range for freshwater.

Conductivity started to increase in the month of January until September with the highest value obtained in the month of March (524.045 $\mu \mathrm{S} \mathrm{m}^{-1}$ ) in Lake Mohicap. Meanwhile, the highest value in Lake Paoay was observed in the months of January and April which coincided with the appearance of Ceratium and Anabaena blooms in Lake Paoay. Ceratium species are known to be classical inhabitants of mineralized waters with high conductivity [27].

Since Lake Paoay is surrounded by crop fields, nutrient inputs may come from agricultural runoff and from the fish pens in the area. The

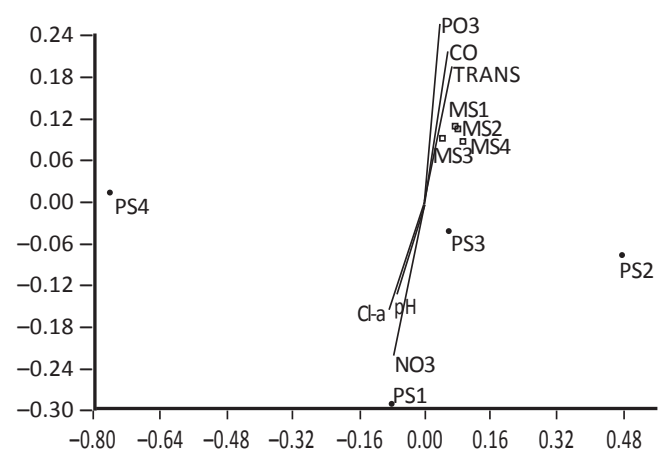

Figure 4. Non-metric multidimensional scaling of Lake Paoay and Lake Mohicap (Legend: PS - Paoay Site; MS - Mohicap Site; CO - Conductivity; TRANS Transparency; $\mathrm{pH}$ - pH; PO3 - Phosphates; NO3 Nitrates; CL-a-Chlorophyll $a$ ) immediate massive inputs of these nutrients had led to Ceratium and Anabaena blooms. These blooms were attributed to sudden changes in vertical stability, depletion of nutrients and alterations in the underwater light climate.

According to Gillbricht [28], the increase in nutrients resulted in the species shift from diatoms to dinoflagellates. A fairly high nutrient inputs of nitrogen and phosphorus were found during the formation of Ceratium bloom in January with $7.94 \mathrm{mg} \mathrm{L}^{-1}$ and $0.82 \mathrm{mg} \mathrm{L}^{-1}$, respectively. An inverse result was found when the cyanobacterium Anabaena appeared in February with a decrease in phosphate while nitrates slightly increased.

Ceratium can develop high densities and biomasses from mesotrophic to eutrophic lakes which are rich in organic matter as organic nitrogen. This is one reason, why they can compete for dominance with cyanobacterial bloom; they can even precede their bloom, more often follow them, and hardly ever codominate with them [29]. Olrik [30] stated that the species of Ceratium often bloom in lakes with strong thermal stability. Chlorophyll $a$ coincided with the occurrence of Ceratium and the cyanobacterium Anabaena, with an increase of Chlorophyll $a$ of $0.085 \mathrm{mg} \mathrm{L}^{-1}$ and $0.147 \mathrm{mg}$

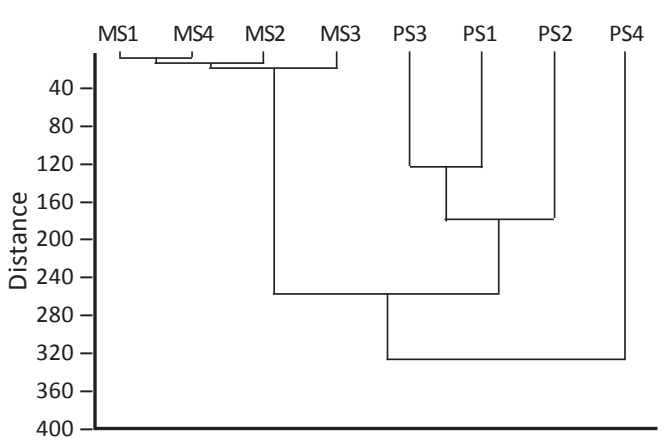

Figure 5. Hierarchical cluster analysis of Lake Paoay and Lake Mohicap (Legend: PS - Paoay Site; MS Mohicap Site) 
$\mathrm{L}^{-1}$ obtained in January and February, respectively.

The highest amount of Chlorophyll $a$ for Lakes Paoay and Mohicap were observed during the month of June which is $0.284 \mathrm{mg} \mathrm{L}^{-1}$ and $0.099 \mathrm{mg} \mathrm{L}^{-1}$. The amount of nitrates and phosphates in Lake Paoay peaked during the wet season, which can be due to the runoff of fertilizers from agricultural areas during the rainy months. The amount of nitrates is observed to be inversely proportional to certain phytoplankton species such as the Cyanophyta. In Lake Mohicap, the amount of phosphates and nitrates occurred differently. During the wet months, nitrates were at their lowest and increased towards summer while phosphates had the highest peaked but decreased towards the summer. The parameters used were able to show the differences between Lake Paoay and Lake Mohicap, that although both of them are located in a tropical country, several factors can affect the succession of organisms and trophic status of the lakes.

\section{Comparative analysis of the different sites of Lake Paoay and Lake Mohicap. The} relationships between environmental parameters and phytoplankton groups for the different sites of Lake Paoay and Lake Mohicap were analysed using the non-metric multidimensional scaling and cluster analysis in PAST. Figure 4 and Fig. 5 imply that the amount of nitrates and environmental parameters such as $\mathrm{pH}$, Chlorophyll $a$, in Lake Paoay sites 2 and 3 were increasing while for Paoay site 4 , the conductivity and transparency were decreasing and is not affected by the mentioned parameters in sites 2 and 3. Paoay site 1 as shown in Fig. 4, was not affected by any parameters used in the study and has other factors which were affecting it.

The presence of four groups of phytoplankton were affected individually by different parameters and can be seen to dominate a specific site. This is true in the case of Dinophyta, its highest density was observed in Paoay site 1 and was not much affected by the parameters used. One factor which might have affected it was the season as it only occurred during the dry cold season. Cyanophyta was observed all throughout the lake but in a variety of density. Its relationship is closer to the decrease in turbidity rather than increase in nitrates although Cyanophyta are known to fix nitrogen compounds. One main reason was the genera that occurred, the lake was dominated by colonial genera like Chroococcus rather than filamentous blue-green algae. Its highest density occurred in site 4 where the amount of phosphates is high in contrast with the other sites. Cyanophyta are known to have high storage capacity for phosphorus as well as high maximum rate of phosphorus uptake [5]. Bacillariophyta and Chlorophyta were observed in nearly equal densities although higher densities were in site 3 and were affected by the different parameters. Euglenophyta was not observed in Lake Paoay since environmental variables were not favorable for its growth.

Sites in Lake Mohicap were more affected by the decreasing conductivity and transparency. High variation in the different environmental parameters were not observed as they occur in almost equal amounts (Fig. 5). This phenomenon might be attributed to the smaller surface area (22.89 ha) of Lake Mohicap in contrast to the bigger surface area (440 ha) of Lake Paoay. Another factor that might have caused this equal measurements of parameters is the difference of shapes of the two lakes. Lake Paoay has an irregular shape while Lake Mohicap is round.

Amount of phosphates were higher in Lake Mohicap in contrast with Lake Paoay since phosphorus can enter the lake from many sources like rain runoff, agricultural nonpoint sources, fertilizers applied to crops, bird and animal waste, plant debris, and detergents [31]. 
This is true for Lake Mohicap since it is being domesticated by people living near the area and is enclosed in one barangay unlike with the case of Lake Paoay wherein there is a variety of nutrient entry coming from four barangays. Cyanophyta had the highest density and this was due to the higher amount of phosphates in Lake Mohicap which also caused the transparency to decrease due to the abundance of colony formations. Low nitrogen and high phosphorus conditions often favor cyanobacteria in fresh and saltwater systems [32] especially for colonial genera such as Microcystis and Chroococcus.

\section{CONCLUSION}

The abundance and distribution of phytoplankton community structure were carried out in Lake Paoay and Lake Mohicap. The results showed that a new record of Ceratium species for the first time was coinhabiting with the other algal groups in Lake Paoay. Cyanophyta was the most dominant among all algal groups in Lake Mohicap in terms of density and was dominated by Bacillariophyta in terms of diversity. Occurrence of Peridinium and Glenodinium in low densities had also been noted. Unusual occurrences of specific genera from different phyla can be attributed to the different changes that the two lakes are undergoing. Such factors that affect their presence are seasonality, and nutrient enrichment. There is still a need for continuous lake monitoring since there were unusual occurrences of other algal species in both lakes. There had been changes among the environmental variables in both lakes. Future research should be focused on the abundance and composition of these freshwater dinoflagellates in both lakes as these can be indicators on rapid changes in lakes.

\section{Acknowledgments}

The authors would like to thank Kenoses L. Legaspi, Lawrence Victor D. Vitug for their assistance during field collection and preliminary analyses. This research was funded by the Commission on Higher EducationPhilippine Higher Education and Research Network (CHED-PHERNet) grant to SFB and RDSP (Project A2).

\section{REFERENCES}

[1] Reynolds CS. Physical Determinants of Phytoplankton Succession. In: Sommer U (Ed.) Plankton Ecology, Succession in Plankton Communities, pp. 9-56. (Berlin, Heidelberg: Springer, 1989).

[2] Li Y, Liu Y, Zhao L, Hastings, \& Guo H. Exploring change of internal nutrients cycling in a shallow lake: A dynamic nutrient driven phytoplankton model. Ecol. Model. 2015; 313:137-148.

[3] Reynolds CS, Huszar V, Kruk C, Naselli-Flores L, \& Melo S. Towards a functional classification of the freshwater phytoplankton. J. Plankton Res. 2002; 24(5):417-428.

[4] Padisák J, Crossetti L, \& Naselli-Flores L. Use and misuse in the application of the phytoplankton functional classification: a critical review with updates. Hydrobiologia 2009; 621:1-19.

[5] Baldia SF, Evangelista AD, Aralar EV, \& Santiago AE. Nitrogen and Phosphorus Utilization in the Cyanobacterium Microcystis aeruginosa isolated from Laguna de Bay, Philippines. J. Appl. Phycol. 2007; 19(6):607-613.

[6] Laguna Lake Development Authority. Water Quality Report of the Seven Crater Lakes. (Environmental Quality Management Division, 2014).

[7] Aquino MR, Cho C, Cruz MA, Saguitguit MAG, \& Papa RDS. Zooplankton Composition and Diversity in Paoay lake, Luzon Is., Philippines. Philipp. J. Sci. 2008; 137(2):169-177.

[8] Papa RD, Wu JT, Baldia S, Cho C, Cruz MA, Saguiguit $A$, \& Aquino R. Blooms of the colonial green algae, Botryococcus braunii Kuetzing, in Paoay Lake, Luzon Island, Philippines. Philipp. J. System. Biol. 2008; 2(1):21-31.

[9] Martinez M, Chakroff R, \& Pantastico J. Direct phytoplankton counting techniques using the haemocytometer. Philipp. Agric. 1975; 59:43-50.

[10] Strickland JDH \& Parsons TR. A Practical Handbook of Seawater Analysis, 310pp. (Fisheries Research Board of Canada, Ottawa, 1972). 
[11] Jackson DA, Walker SC, \& Poos MS. Cluster Analysis of Fish Community Data: "New" Tools for Determining Meaningful Groupings of Sites and Species Assemblages. Am. Fish. Soc. Symp. 2010; 73:503-527.

[12] Villaroman KMD, Arguel MKC, \& Baldia SF. Temporal Trends in Phytoplankton Diversity of Paoay Lake (Ilocos Norte, Philippines). Acta Manilana 2010; 58:31-39.

[13] Stevenson J, Siringan F, Finn J, Madulid D, \& Heijniss H. Paoay Lake, Northern Luzon, the Philippines: a record of Holocene environmental change. Glob. Change Biol. 2010; 16:1672-1688.

[14] Cordero CS \& Baldia SF. Temporal variation of phytoplankton community structure in Lake Mohicap, San Pablo City, Laguna, Philippines. Int. J. Pure App. Biosci. 2015; 3(2):377-385.

[15] Zafaralla MT. Microalgae of the Seven Lakes of San Pablo City and Crocodile Lake of Los Baños 2014.

[16] Venkatachalapathy R, Nandhakumar G, \& Karthikeyan P. Diatoms Community Structure in Relation to Physic-Chemical Factors in Yercaud Lake, Salem District, Tamil Nadu, India. Int. J. Innov. Technol. Exploring Eng. 2013; 2(4):220-222.

[17] Mowe MAD, Mitrovic SM, Lim RP, Furey A, \& Yeo DCJ. Tropical cyanobacterial blooms: a review of prevalence, problem taxa, toxins and influencing environmental factors. J. Limnol. 2015; 74(2):205224

[18] Graham HW \& Bronikovsky N. The genus Ceratium in the Pacific and North Atlantic Oceans. Carnegie Inst. Wash. Publ. 1944; 565 (209pp.).

[19] Gómez F. Reinstatement of the dinoflagellate genus Tripos to replace Neoceratium, marine species of Ceratium (Dinophyceae, Alveolata). CICIMAR Oceánides 2013; 28(1):1-22.

[20] Graham SW. An oceanographic consideration of the 'dinoflagellate genus Ceratium. Ecol. Monogr. 1941; 11:99-116.
[21] Nordli E. Experimental studies on the ecology of ceratia 1957; 8:200-265.

[22] Lund JWG. The ecology of the freshwater phytoplankton. Biol. Rev. 1965; 40:231-293.

[23] Tundisi JG, Matsumura-Tundisi T, Pereira KC, Luzia AP, Passerini MD, Chiba WAC, Morais MA, \& Sebastien NY. Cold fronts and reservoir limnology: an integrated approach towards the ecological dynamics of freshwater ecosystems. Braz. J. Biol. 2010; 70(Suppl. 3):815-824.

[24] Van Ginkel Ce, Hohls Bc, \& Vermaak E. A Ceratium hirundinella (O.F. Müller) bloom in Hartbeespoort Dam. Water SA 2001; 27(2):269-276.

[25] Nakano S, Nakajima T, Hayakawa K, Kumagai M, \& Jiao C. Blooms of the Dinoflagellate Ceratium hirundinella in large enclosures placed in Lake Biwa. Jpn. J. Limnol. 1999; 60:495-505.

[26] Wu JT. Phytoplankton as bioindicator for water quality in Taipei. Bot. Bull. Acad. Sinica 1984; 25:205-214.

[27] Gil CB, Restrepo JJR, Boltovskoy A, \& Vallejo A. Spatial and temporal change characterization of Ceratium furcoides (Dinophyta) in the equatorial reservoir Riogrande II, Colombia. Acta Limnol. Bras. 2012; 24(2):207-219.

[28] Gillbricht M. Phytoplankton and nutrients in the Helgoland region.-Helgoländer Meeresunters 1988; 42(3):435-467.

[29] Reynolds CS. Vegetation Processes in the Pelagic: a model for ecosystem theory, 371pp. (Germany: Ecology Institute, 1997).

[30] Olrik K. Phytoplankton Ecology. Determining factors for the distribution of phytoplankton in freshwaters and the sea. Denmark: Danish Environmental Protection Agency. Miljÿproject No. 251. 1994 (183pp.)

[31] City of Lakeland Lake Report 2009.

[32] Kuffner IB \& Paul VJ. Effects of nitrate, phosphate and iron on the growth of macroalgae and benthic cyanobacteria from Cocos Lagoon, Guam. Mar. Ecol.-Prog. Ser. 2001; 222:63-72. 